\title{
Digital Technology and Interior Architecture
}

\author{
Deniz DEMIRARSLAN ${ }^{1}$, Oğuz DEMIRARSLAN ${ }^{2}$
}

\begin{abstract}
Defined as the electronic demonstration of data on a screen, the digital concept has become a ubiquitous notion in the entire world and all aspects of life particularly after the onset of the 2000s. Video, camera, computer, mobile phone, television, watch, medical devices, laser gauge devices, electronic kitchen utensils, air conditioners and a myriad of products that develop and operate via digital technology have become widespread in daily life. Digital technology, in its shorter definition, refers to the type of technology that facilitates the generation of electronic screen equipment, gadgets and machines in which numerical data are converted into useful, comprehensible information in order to simplify the life of users. In addition to offering fast, practical and widespread applications once used, digital technology products also cater to novel areas of usage each new day thanks to developing technology. One of these areas of usage is interior architecture. Interior architecture designs have been performed on digital media as of the second half of the 1990s and with the advent of the 2000s, novel digital technology processes such as 3-Dimensional works became popular to save time and develop innovative designs. Via using digital presentation in multidimensional, visual, or artificial media, the design manages to exist even before physical production while the design process is also moulded by representation. In the design process, problems can be resolved quickly allowing reductions in electricity and cash resources possible. Moreover, it is also viable to avoid potential mistakes. Currently, some of the common digital technology uses in interior architecture are; 2 and 3-Dimensional drawing and modelling programs on a computer, liquid theories, parametric design, computer coded production programs, simulation programs, artificial intelligence products, virtual reality (VR) and 3-Dimensional printer systems. Within the interior architecture itself, there are numerous design products generated via digital technology are used. On the other hand, to improve user comfort in spaces, applications are formed by utilizing digital technology and there is a gradually increasing demand for such applications. In this study, the uses and effects of digital technology particularly in the interior architecture will be analysed. The aim of this study is to provide an important written resource for futuristic approaches to interior architecture.
\end{abstract}

Keywords: Digital world, interior architecture, design, smart space, virtual space.

\section{Dijital Teknoloji ve İç Mimarlık}

Öz

Verilerin bir ekran üzerinde elektronik olarak gösterilmesi şeklinde tanımlanan dijital kavramı, özellikle 2000'li yılların başından itibaren tüm dünyada ve yaşamın her alanında yaygın bir şekilde etkili olmaktadır. Kamera, fotoğraf makinesi, bilgisayar, cep telefonu, televizyon, saat, tıp cihazları, lazer ölçüm cihazları, elektronik mutfak aletleri, klima gibi çok sayıda dijital teknoloji ile gelişen ve çalışan ürün günlük yaşamda kullanılmaktadır. Kısacası "dijital teknoloji", bireylerin hayatlarını kolaylaştırmak amacıyla, sayısal verilerin anlaşılabilir ve işe yarar bilgilere dönüştürüldüğü, elektronik ekranlara sahip araç-gereç, alet ve makinelerin üretilmesine olanak tanıyan teknolojidir.

\footnotetext{
${ }^{1}$ Kocaeli Üniversitesi Mimarlık ve Tasarım Fakültesi İç Mimarlık Bölümü

2 Maltepe Üniversitesi Mimarlık ve Tasarım Fakültesi İç Mimarlık Bölümü,

* İlgili yazar/Corresponding author: denizdemirarslan@gmail.com

Gönderim Tarihi: 28.08.2020

Kabul Tarihi: 15.12.2020
} 
Dijital teknoloji ürünleri kullanıldıklarında hızlı, pratik ve her yerde kullanım imkânı sağlamalarının yanı sıra, her geçen gün gelişen teknoloji sayesinde yeni kullanım alanları da sağlamaktadır. Bu kullanım alanlarından biri de iç mimarlıktır. İç mimari tasarımlar 1990'ı yılların ikinci yarısından itibaren dijital ortamda yapılmaya başlanmış; 2000'li yıllardan itibaren de zaman kazanmak ve tasarımların da gelişebilmesi için 3 boyutlu çalışmalar gibi dijital teknoloji süreçleri kullanılmaya başlanmıştır. Çok boyutlu, görsel veya sanal ortamlarda dijital temsilin kullanılmasıyla, tasarım daha yapılmadan var olabilmektedir ve tasarım süreci de ona göre şekillenmektedir. Tasarım sürecinde sorunlar hızlı bir şekilde çözülmekte, enerji ve maddi kaynak tasarrufu yapılabilmektedir. Ayrıca olası hatalardan kaçınılması da söz konusudur. Günümüzde iç mimari tasarımda dijital teknoloji kullanımı olarak, bilgisayarda 2 ve 3 boyutlu çizim ve modelleme programları, likit kuramları, parametrik tasarım, bilgisayar kodlamalı üretim programları, simülasyon programları, yapay zekâ ürünleri, sanal gerçeklik (VR), 3 boyutlu yazıcı sistemleri yaygın bir şekilde kullanılmaktadır. İç mekânın kendisinde ise dijital teknoloji ile üretilmiş sayısız tasarım ürünü kullanılmaktadır. Öte yandan mekânlarda kullanım konforunu artırmak amacıyla dijital teknolojiden yararlanılarak uygulamalar yapılmakta ve bu tür uygulamalara gün geçtikçe rağbet artmaktadır. Bu çalışmada ise iç mimarlıkta ve iç mekânın kendisinde dijital teknolojinin kullanımı ve etkileri incelenecektir. Çalışmanın iç mimarlık alanında gelecekçi yaklaşımlar için önemli bir yazılı kaynak oluşturması amaçlanmaktadır.

Anahtar Kelimeler: Dijital dünya, iç mimarlık, tasarım, akıllı mekân, sanal mekân.

\section{INTRODUCTION}

"We, the Designers, stand at the intersection of Science and Art." Eşref Zeki Parlak

Defined as a type of technology based on numbers, there is a growing area of usage for digital technology. In the 21st century, the world started to move from industrial society to information society, and the century we now live in started to be termed as "Information Age". As an effect of globalization, a new model of living started to quickly dominate the world. "Digitalization Process" also defined as the "Digitization Process" in Turkish language is explained as the transformation process from analogue to digital format. Digitalization is using digital technologies to develop a business model and generate new opportunities that can generate income and value (Yankın, 2018, p. 9). Digitalization can be defined as a systemic transformation of human, functional and technical factors accomplished by organisations to ensure more effective, efficient services and customer satisfaction in line with the opportunities provided by rapidly changing information, communication technology and evolving social needs (Yazar and Yalçın, 2018, p. 613). In its shorter definition, "digital technology" relates to the type of technology that allows generating electronic screen equipment, gadgets, machineries in which numeric data are converted into useful and comprehensible information to the end of simplifying users' life (Yazar and Yalçın, 2018, p. 613). Every single product that develops and operates via digital technology (video, camera, computer, mobile phone, television, watch, medical devices, laser gauge devices, electronic kitchen utensils, air conditioner, etc.) makes life easier for humans every day. These products offer advantages in various areas of interior architecture (Gere, 2019, p. 17). Undoubtedly, the recent increase of artificial intelligence studies and the use of artificial intelligence products in the area of interior architecture have also been effective factors behind the emerging trend. Digital technology has been a common technique in interior architecture since the 1990s. 
Digital technology is used in two separate processes in the field of interior architecture:

a) In the design process of interior space,

b)In the usage process of interior space.

Interior architects investigating the defined issues with the functionality of interior spaces and the design of aesthetic spaces (Demirarslan, 2006, p. 7) make heavy use of emerging technology in the design and use of space processes. Indeed, interior architecture has now become an inseparable entity of digital technology.

\section{USING OF DIGITAL TECHNOLOGIES IN THE DESIGN PROCESS OF AN INTERIOR SPACE}

In the design process of interior space, the use of digital technologies takes place in 4 different styles:

- Digital Design: Drawing, Modelling, Presentation.

- Digital Production: CNC, 3D Printer, Laser 3D Scanner.

- Parametric Design, Animation Technologies, and Virtual Reality.

- Digital Space Design: Cyberspace and Liquid Design.

\subsection{Digital Design: Drawing, Modelling, Presentation}

The technical drawing has been undoubtedly a manifestation of the design of space. The plan for the construction of a temple, which dates back to around 4000 years ago, is reportedly one of the oldest architectural sketches on the Gudea Monument in the Louver Museum (Figure-1). Upon planning the spaces via technical drawing, it was a common practice to pair the performance in a model. For example; it is stated that a 3dimensional analysis was carried out using a model technique in the construction of the Samos Water Canal, which was designed by Eupalinos of Megara in the 6th century $\mathrm{BC}$ and is now considered a geometric marvel (Olson, 2012, p. 30).
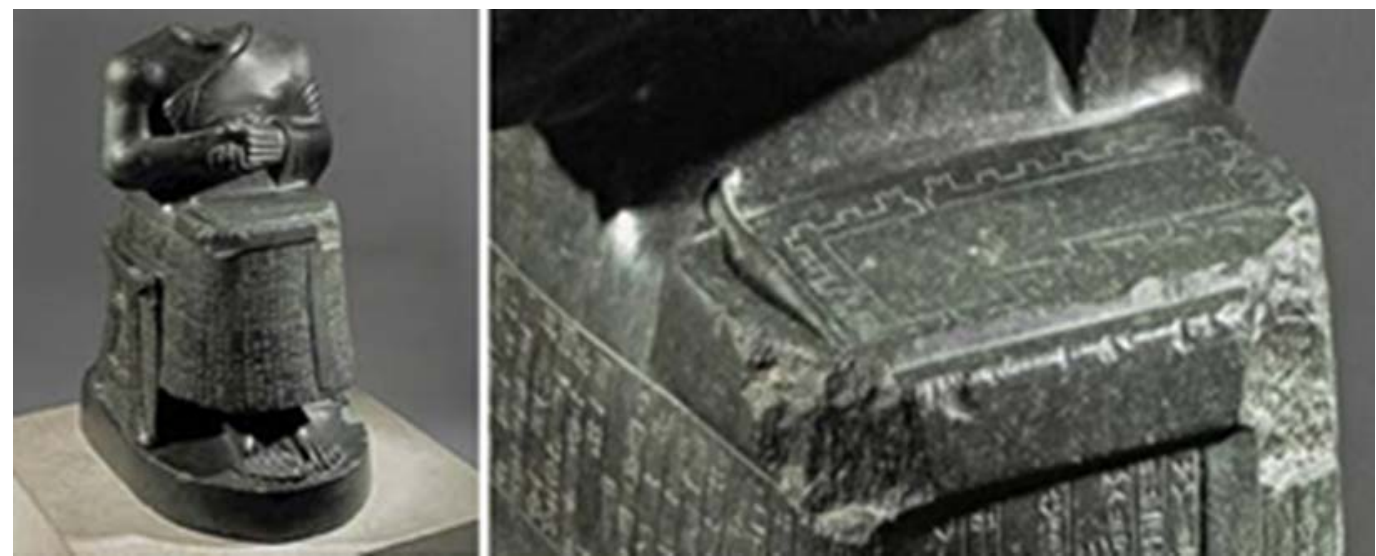

Figure 1. The Gudea Monument and Plan Drawing, Louvre Museum (URL-1).

One of the most famous architects of antiquity, Vitruvius, described drawing as a tool for the presentation of the design. That is why Vitruvius concluded that the architect should have a thorough understanding of geometry to help him make a good drawing and apply his drawing (Pilsitz, 2017, p. 72-78; Demirarslan, 2006, p. 4). Besides technical drawing, model, cast, and prototype work also helped the architects mould and present design. In the creation of architectural space during the Renaissance, Baroque, Neoclassical ages and the 20th century, painting, modelling, moulding and prototype methods were used in the design and presentation of the work. However, with the development of digital technology in the 1960s, it was possible to do technical drawing and presentation work in computer media; with the rise of computers in the 
1990s, the use of computers in architecture was observed (Grisalena, 2017, p. 3,4). While the early experiments that enabled computer-assisted design success started in 1961, the development of the AutoCAD software program in 1982 heralded a revolution in the use of digital technology for space design (Figure-2) (Roberts, 2005, p. vii; Shih, 2020, p. 4).
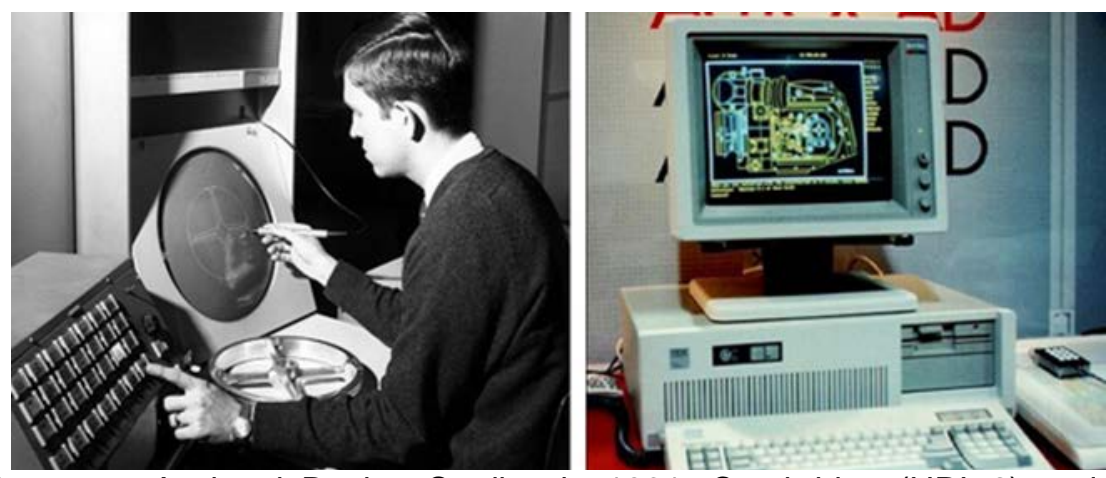

Figure 2. Computer Assisted Design Studies in 1961, Cambridge (URL-2) and 1982-Dated Architectural Drawing via AutoCAD Program (URL-3).

In essence, using computers as a product of digital technology in space design enjoys a relatively brief history. Despite being quite a novel application in the design of space for software, hardware and even information technology, due to the extremely rapid growth of digital technology, there has been a steady rise in its areas and benefits of use. Indeed, computerized technologies have become truly essential ingredients of space design.

Application of digital technology that began via computer-assisted drawing in the field of interior architecture has reached beyond computer-assisted modelling and production process. In 1990, 3D Studio 1.0, the first edition of 3D StudioMax, was developed as the most common software in the field of interior architecture. In the same age, aside from three-dimensional software programs Adobe Photoshop and similar graphic design and editing programs were introduced, and computers' superiority in visualization works was thus proven (Atılgan, 2006, p. 16). Not only computers but digital cameras, videos, printers, scanners, power presses, tablets, gauge devices, and the internet are also assisting interior architects in the field of design. AutoCAD, Real CAD, Revit, 3DMax, Sketch-up, ArchiCAD, Revit, Cinema 4D, Interior Design Cad, Vector Works and several other programs enable the development of two-and three-dimensional space, equipment, construction elements, environmental components and realistic figures (Riccobono, 2013, p. 35). While gauge systems allow measurements to be carried out; cameras, videos and related items record viewing of spaces, graphic programs make the use of display techniques viable; and by 2D and 3D printers, designs can now be converted to 2 and 3D formats (Figure-3, 5). In that sense, however, the greatest advancement of the modern age has been using robot technologies in the field of architectural drawing. By means of robots as an artificial intelligence product, it is possible to create not only overtly-complex drawings but also possible to utilize robots in the application of these drawings. In addition, these robots can, in the shortest and most accurate way possible, achieve the optimization of space and its elements (Figure-4). 

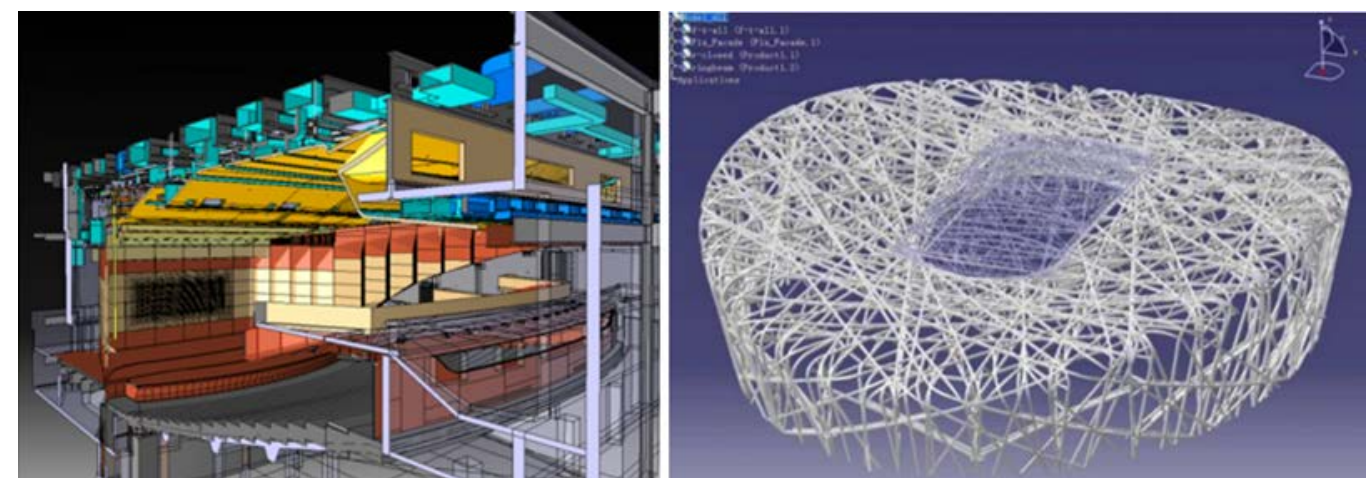

Figure 3. Computer Assisted Design Studies in this Age, Frank Gehry (URL-4).
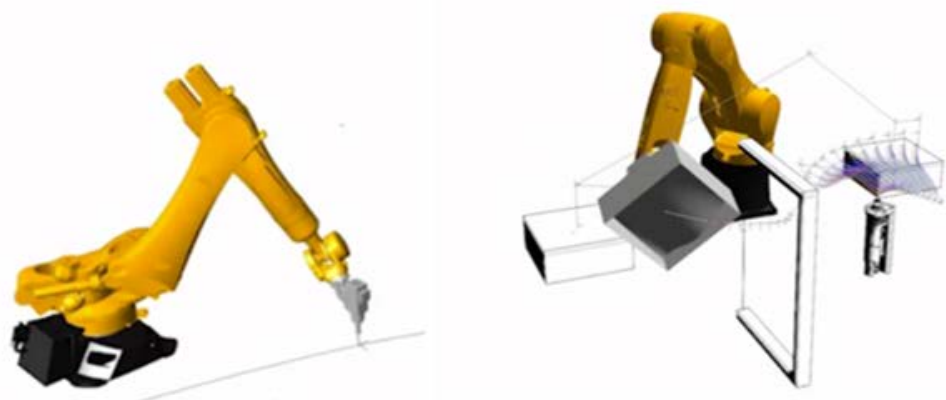

Figure 4. Using Robot Technologies in Drawing (URL-5).

On the other hand, artificial intelligence and fuzzy logic systems are utilized in interior architecture drawings. Artificial intelligence is defined as an operation aiming to make machines intelligent (Nilsson, 2019, p.13). In parallel with developing technology, artificial intelligence systems can offer an insight into various other fields one of which is interior architecture. Operations that are based on human-like thought and that are capable of transforming human-like thinking into mathematical functions are known as "fuzzy logic," which is often widely used in modern-age interior designs. By developing a drawing program operating via an artificial intelligence method, it is feasible to perform equipment zones having predefined spatial relations by generating different alternatives in an easy and swift manner. In the interior architecture process by the fuzzy logic system, fuzzy-logic based systems are utilized to analyse the spatial needs of the space to be designed (Yıldırım and Demirarslan, 2020, p. 70).

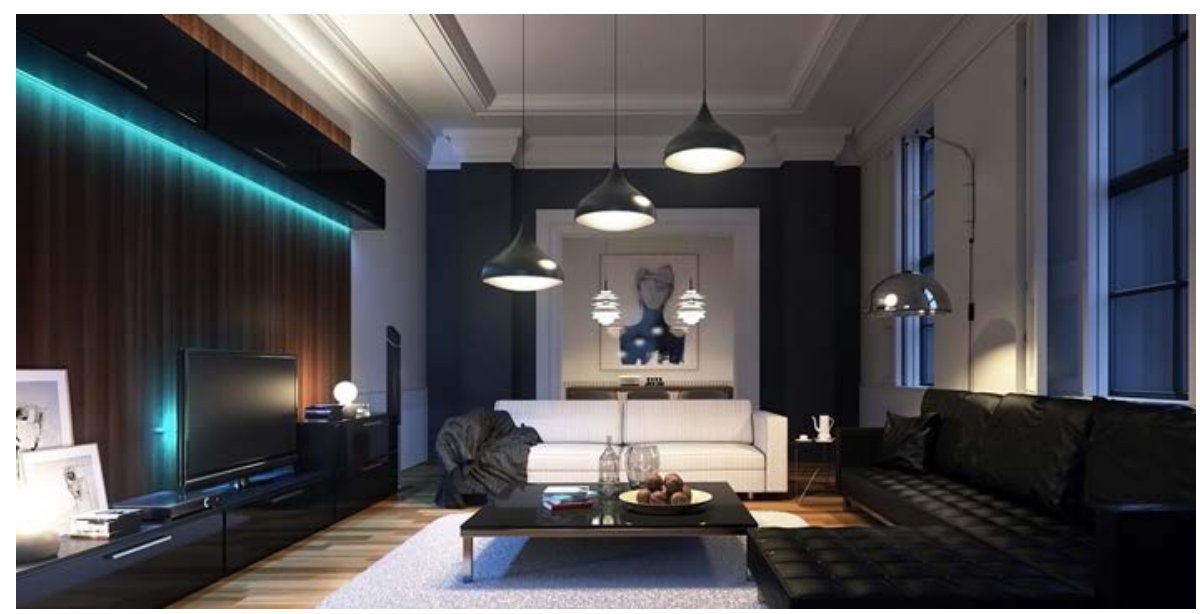

Figure 5. A 3D Interior Space View by Using Max Program (URL- 6). 


\subsection{Digital Production: CNC, 3D Printer, Laser 3D Scanners}

The first name that comes to mind upon hearing digital production is CNC Technologies. CNC Technologies that refer to computer numerically controlled are the machines that operate automatically after being programmed by a computer that is fixed onto a machine. Thanks to this machinery, the production of numerous spaces and construction elements is achieved. In the production sites of interior architecture, there is growing popularity in using CNC router and turning machines, wood processing machines, and similar machinery (Riccobono, 2013, p. 291). 3-dimensional printers, on the other hand, play a vital role in cast presentation technique and prototype production in interior architecture and in equipment component design (Figure-6). The 3dimensional printer performs printing works of ".stl' extension files and the product is thus generated. Technology is so advanced in that sense that not only space components and equipment components but also the production of an entire building is achievable (Figure- 7). Laser 3D scanners also go beyond making all kinds of measurements of space with the help of artificial intelligence technologies and also manage to offer a visual certification by making its drawing (Riccobono, 2013, p. 280). So much so that, due to the advantages presented in the field of interior architecture, a new era has started with the latest digital technologies.

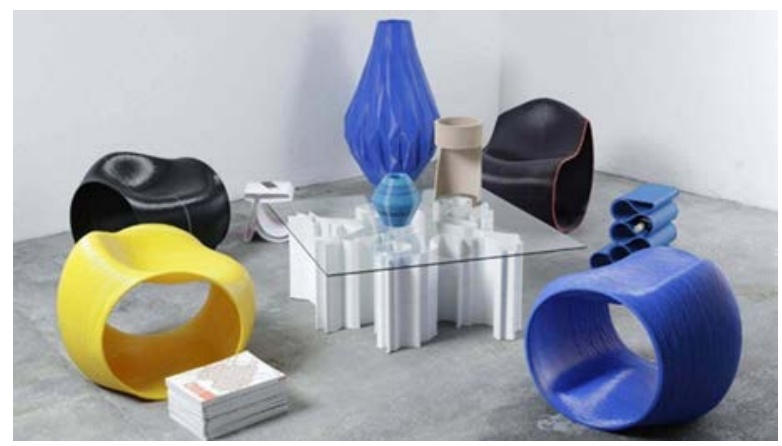

Figure 6. Furniture Samples Produced via 3D Printer (URL-7).

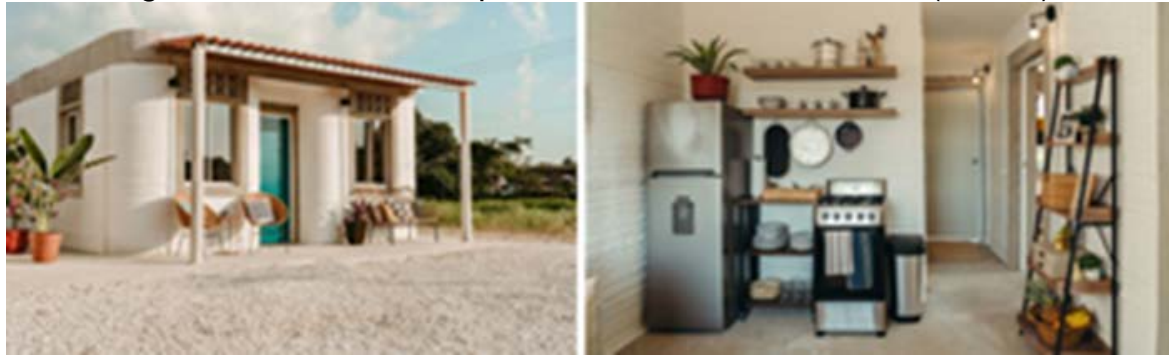

Figure 7. A House and Its Interior Space Image Produced via 3D Printer (URL-8).

\subsection{Parametric Design, Animation Technologies and Virtual Reality}

Although using the parametric approach in space design goes back to the past, the computer-assisted parametric design has gained more popularity in recent years. The parametric design developed by the use of definite parameters such as number and algorithm was again implemented in computer-assisted media under the leadership of designers such as Christopher Alexander, Zaha Hadid, Frank Gehry, Shigeru Ban (Figure- 3, 8). The 1990s, in particular, was defined as "Digital Decade" by means of architects' works in computer-assisted media. Architectural Design Journal described architects conducting works in this period as "Cyberspace Architects" and the architecture performance as "Post-Geometry Architecture" (Grisalena, 2017, p. 12).

Compatibility, speeding of the design process, the ability to use various sources are recorded benefits of parametric design, but the main advantage is that the design process can be easily controlled and managed. Thanks to the animation made by this 
technique, the way how interior design would look after application as a significant presentation technique has been demonstrated. In fact, animation is a technique for creating a motion picture. In the past images were formed individually by using hand drawings, photo techniques, 2-dimensional images on computer media, 3-dimensional digital models, or physical models while animation offers benefits for selecting form in the uses of parametric design in the concept- development stage. Animation technologies allow the inclusion of time and motion conceptually into the design (Akipek and İnceoğlu, 2007, p.237-253). Virtual spaces are formed through these technologies. This phenomenon that can literally be described as virtual reality is known to be a virtual world created by distancing the person mentally from the existing physical space and setting. In this new setting, a person can shape experiences by touching, modifying the features and positions of artificial objects in virtual space, and through such interactions, individuals can create emotional reactions that are much reminiscent of the setting in the real world (Yıldırım and Demirarslan, 2019, p. 162). By using virtual reality technologies in interior architecture, designers' motivation escalates, creativity flourishes, and a favourable setting can be offered to generate novel design ideas and to put them into practice. Designers can reveal the designed space more conveniently to viewers by making use of virtual reality technologies. At the implementation level, too, there is a simpler manufacturing system for producers and the error rate is also minimised. (Şekerci, 2017, p. 1356-1362).

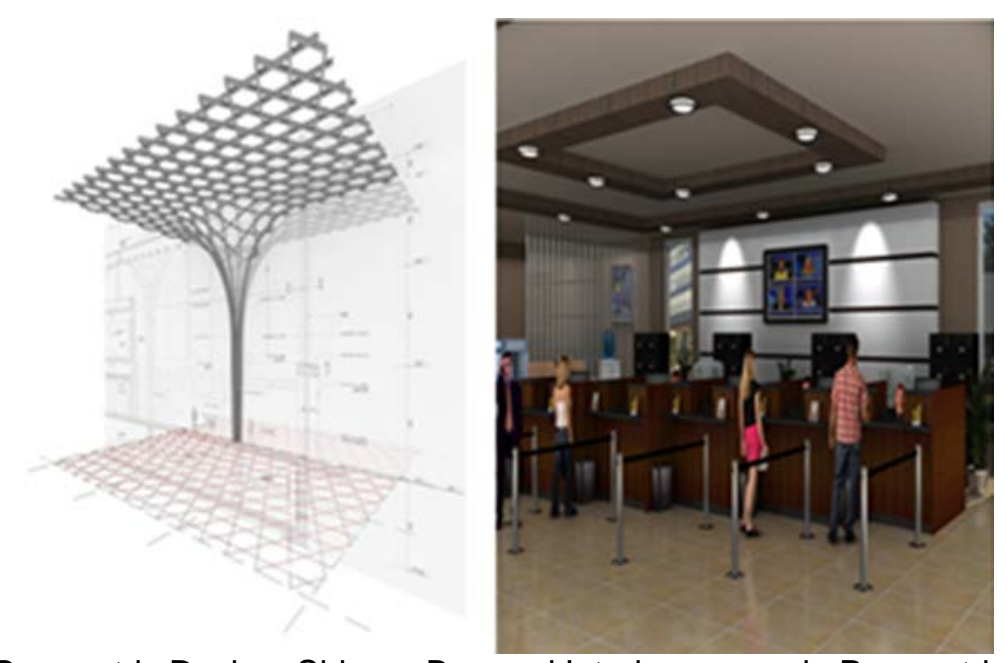

Figure 8. Parametric Design, Shigeru Ban and Interior space via Parametric Animation Technique (URL-9).

\subsection{Digital Space: Cyberspace and Liquid Design}

"Cyberspace" as a term is a metaphoric abstraction explaining virtual reality media that emerges out of the communication between computers and computer users through the internet and similar network connections. It is also defined as "cyber environment". Cyberspace stands for the technological integrity of the developing world (Güntay, 2019 , p. 89). Cyberspace is the place in which all information continues to exist eternally within a global unity. Because of cyberspace's 'eternal space' feature, cyberspace is the same as nowhere at the same time. In another way, cyberspace stands for a world formed by computers, and societies are formed around these computers (Özdemir and Şahin, 2005, p. 7).

This concept was used for the first time in 1984 by a science-fiction writer William Gibson in his novel "Neuromancer". In his novel, Gibson described cyberspace as a virtual network system that connects all humans ( Çiftçi and Demirarslan, 2020, p.65). 
Indeed, the fact that modern internet network connects all people in the world and form a virtual universe can be taken as another version of cyberspace application (Yayla, 2013 , p. 180). Developments in cyberspace that rules out the dependency on space annihilate space functions and change the way we live. For instance, shopping on the internet rather than in shops or malls in this age promoted web-page design rather than shop design. Borders between spaces were removed, accessibility and intercultural communication climbed. As a result of developing technologies, the tendency of people to use spaces in digital media -via cyberspace- without needing physical space, weakened physical communication in spaces among humans and equipment as well as the removal of space users are among the vital factors suggested considering for designs in the future. "Designing spaces for the digital self in the alternate world of physical reality; walls shaped by bytes, corridors lined with functions; is it likely that architects are already creating a universe that no longer exists? " (Özdemir and Şahin, 2005, p. 7).

Liquid design in its simplest definition is the name for designs that can expand or contract in line with the expansion and contracting of the scanner screen. Therefore, on a computer media, an interior space or interior architecture product can easily be checked on the screen by performing expansion and contracting (URL-10).

\section{USING OF DIGITAL TECHNOLOGIES IN THE USAGE PROCESS OF AN INTERIOR SPACE}

As mentioned earlier, at the design stage of interior space today, digital technologies are widely used in drawing, presentation, 3-dimensional presentation works, animation techniques, gauging techniques, virtual reality, etc. On the other hand, it is apparent that there is also an increasing need within space for the use of digital technologies as a result of rapidly changing technical advances, sustainability, economic viability, satisfying conditions of luxury, easy living, and the space required by life itself. Yet even before the emergence of digital technology, there were several novelties in history to offer comfort for users in interior space. For instance, in the early 20th century (between 1915-1920 in particular) generated vehicles, electrical machines, vacuum cleaners, food processors and sewing machines entered households for the very first time. However, because the use of electricity was rare, these devices remained mere fantasies created by high technology. There was a related rise in the usage of washing machines and vacuum cleaners during the period from 1920-1940, as a result of the increased use of electricity in households. Washing laundry and vacuuming the floors have become more common. Due to the Second World War from 1940 to 1945, women started to be active members of work-life thus researches and studies to make home-life more comfortable regressed. Upon the end of the Second World War, as men returned to work-life, a lot of new machinery such as refrigerator, electric stove, oven, iron, laundry folding machine, and television gained impetus to convince women return to work life and simplify life at home. As women once again entered work life in the 1960s there was a rise in labour-saving technologies such as water heaters, toasters, stoves, tea and coffee machines, food processors, hair driers, electric shavers, washing machines, sewing machines, vacuum cleaners, and irons. Besides, central heating is also accepted as one of the assets that elevate comfort in interior space (Harper, 2003, p.10).

In 1962-dated cartoon The Jetsons, characters lived a new version of modern American culture and lifestyle that was adapted to a different time. Characters lived in a future utopia in which robots, aliens, holograms and incredible inventions coexist. In 
this animation where robots complete house work, teleportation travels through spaces, people travel by foldable and flying vehicles, a computer conducts kitchen activities, sofas stand on air against the odds of gravity were only a few utopian views that were literally incomprehensible to people living then. But in our age, these products seem probable given the capacity of modern technology. Although smart space technologies came to existence in 1984, during the period of 1960 to 1967 in Stanford Research Institute (SRI), relevant researches were already conducted but these researches failed to be sustainable since in the 1960s there was lack of motivation to improve efficiency in house works, technology users rarely participated in the design process and product designers believed in the deficiency of technology. Yet in the 1980s National Association of Home Builders in the USA integrated emergent technology into the design of new houses and marketed these residences named as "Smart House" for sale. These spaces in which energy-saving and telecommunication techniques accentuated features not gained acclaim in those years (Aldrich, 2003, p. 21). But according to Keyder, "We have been living in a new world since 1980. In this world, the management of the economy is gradually taken into the hands of the capital" (Keyder 2004; Tunalı, 2019: 246). The modern world order is also very successful in improving and shaping cities and architectural spaces. Smart technology developed with the aid of the economy and technology is used in all fields since 1980.

In the modern age, on the other hand, the usage process of interior space first brings to mind smart spaces that are established upon digital technology. This technology that has various names such as smart architecture, smart building systems, smart residence, and smart space will be referred to as smart space in our research. Smart architecture or smart building concept entails all edifices such as hotels, hospitals, office buildings, schools, residences whereas residence only relates to houses. The smart building concept is defined as a building that integrates several systems to efficiently manage resources in a coordinated way to the end of maximizing users' performance, boost saving and flexibility in the earliest investment and downsize operational costs (Çağlayan, 2002, p. 13). However as digital technology is embedded as a component in the design of outdoor spaces, the same definition does not answer the new era.

In essence, the smart space concept refers to all of these spaces regardless of being open or closed, large or small, vertical or horizontal. Smart space is a kind of domain equipped with data processing and within the scope of information technologies that predict and fulfil potential needs, technology management enables to control of the connection of users with space and its further expansion to promote comfort, convenience, security, work and entertainment. Within the context of information technologies that can predict and fulfil the needs (Aldrich, 2003, p. 17). In fact, regardless of being a smart building or a smart space, the main goal in all of them is to make the control network dominant in space media (interior and exterior space alike).

Smart spaces, in a broader sense, can be explained such; the kind of complex and adaptable spaces having a passive and active technological, connected, and globally computed network and architectural strategies to the end of forming an evolutionist unity with users (Senagala, 2006, p.36). Smart space concept entails in itself many disciplines. In addition to the fields of mechatronics, electronic, electric, computer, mechanical and environmental engineering, architecture, interior architecture, industrial product design, and similar branches of design are studied collectively. If space or a given design is smart, it offers the users a means to obtain autonomous information, application, and environmental control. Thus, smart space refers to the combination of systems allowing users to acquire information on the environment, adapt the 
information and develop their experience in this space (Cook and Sajalvd, 2007, p. 153). Energy-efficient spaces, kinetic design, environment-friendly, sustainable and futurist approaches, fast and easy life constitute the core of this system. The scale of smart spaces is applied on a wide scale ranging from cities, structure groups, edifices, spaces to space furnishing-elements (Herzberg, 2017). In summary, smart spaces are described as the use of most modern technologies of the era to fulfil consumer needs and to achieve maximum adaptation in all aspects (Wingginton and Harris, 2002, p. 17).

In modern technologies the features that gain smart feature to spaces can be outlined as below:

- Controlling heating systems via smart technology: It is possible to control the thermal comfort of space at the optimal and necessary temperature level by using smart technology. It could also be possible to make some improvements to ensure energy efficiency.

- Controlling lightning systems via smart technology: By using smart technology in natural and artificial ventilation systems, it is possible to provide spatial physical comfort in a manner that ensures energy efficiency.

- Offering spatial physical comfort via remote control systems: By using smart technology, power, heating, ventilation, kitchen and bathroom appliances and related systems and furniture can be worked in a controlled manner. In this way, it is possible to control not only lightning and heating equipment but also security, audio-visual systems, curtains, kitchen and bathroom equipment and various devices by merely WAP, SMS or dial tone in a mobile phone (Figure-9 and Figure-10).

- Controlling facade and window systems via smart technology: It is possible to control facade and window systems by means of smart technology that handle daylight infusions into space and use climate and energy sensitive and adaptable artificial lighting systems.

- Collecting and controlling environmental data via smart technology: Environmental data is required to form in many spaces the kind of abovementioned features through the help of smart technology and collecting data on the environmental conditions for interior and exterior space is a major determinant in the control decisions of smart technologies. Indoor and outdoor environments' air temperature, humidity levels, wind speed and direction, facade and room temperatures, indoor air quality ratios, daylight ratios and related environmental data are detected using smart technologies and are used to control different space and interior design features.

- Allowing to detect learning ability via smart technology: By utilizing current and expected data on air conditions to compute optimum value in the space as well as preheating of space, arranging lightning and shading levels, using information-based software algorithms that entail neural networks and fuzzy logic, create the kind of spaces having the ability to learn energy status and thermic features are now possible in modern age.

- Forming and controlling the brain of space: What matters most for smart spaces is "brain" that replicates the form of a space-control system and this is a central processing unit. Through data released from several sensor stations, it is feasible to perform many actions let it be monitoring weather changes or energy usage and more.

- Controlling security and escape systems for a safe life: It relates to managing disaster protection and escape systems, thief tracking, protection and notification systems. They are the kind of systems that perform predetermined procedures in the face of any disaster that can occur due to accidents or natural 
causes in space and these systems are operated by a fuzzy logic mechanism that can be defined as the newest development of digital electronics (Çağlayan, 2002, p.56).

- Spaces that have smart objects possess individual and independent devices and objects which can operate in smart manner.

- In spaces that have smart objects which can communicate, functionality is enhanced by allowing information exchange between devices and objects.

- Via smart technology, it is possible to interconnect numerous spaces located in different positions.

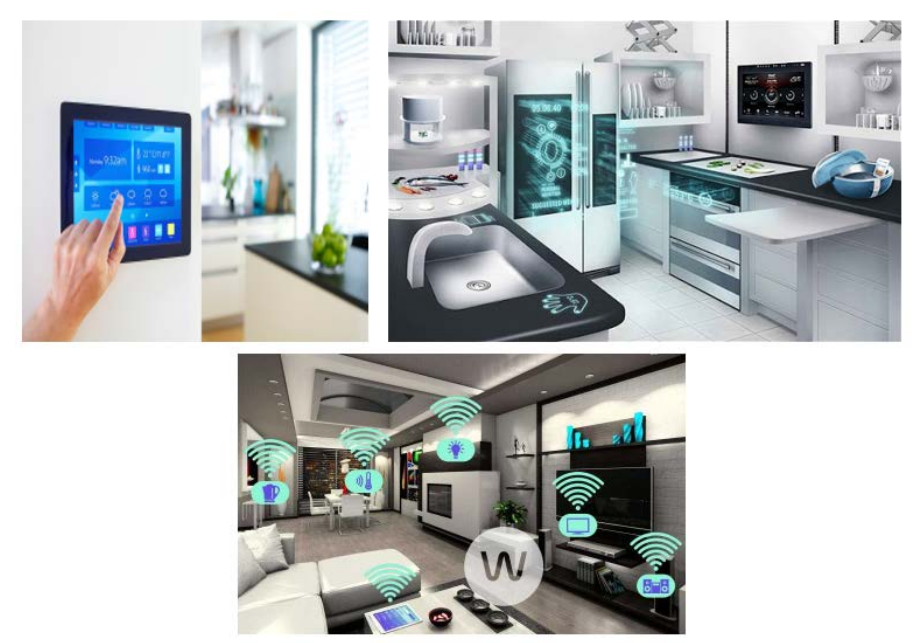

Figure 9. Use of Digital Technology in Interior Space - Smart Space Technologies in Residences (URL-11).
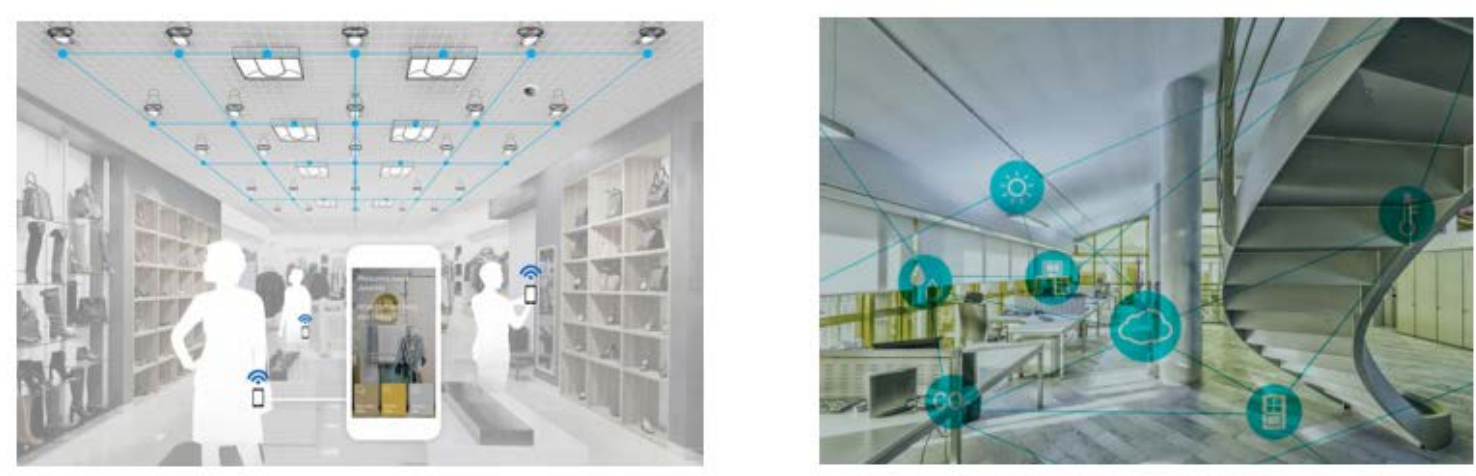

Figure 10. Use of Digital Technology in the Interior Space - Smart Space Technologies in Malls and Offices (URL-12).

For a design to be smart, space must consider the entire life cycle as well as several of its systems and components. A smart interior space connects national construct materials and artworks of local craftsmen; benefits from user intelligence; cooperates with the management team on fine tuning and procedural works; reflects aesthetical traits of cultural heritage; evolves on a daily and yearly basis; while also exists in harmony with local micro-climate and local aesthetical approach. Despite the potential complexity of a smart space, it is mainly expected to have a simple character to operate; to utilize energy and resources efficiently; to be easily renewable; to be maintained; to be adapted and be treated by recycling processes (Çağlayan, 2002, p. 68). 
Thanks to these inherent properties, smart spaces have rapidly become the latest trend in the world. It is projected that between the period of 2019-2024, the smart space market will have risen by a growth rate of 23\% (URL-13). Increasingly, all countries have been turning towards smart designs and advanced smart cities or smart residences and a myriad of life- facilitator designs for users in an attempt to boost efficiency and lower operational costs.

\section{CONCLUSION}

In this age when digitalization is defined as a holistic transformation of human, operational procedure and technology factors achieved by organizations to assure more effective, efficient services and user satisfaction in accordance with the opportunities offered by rapidly developing information and communication technologies and evolving social needs, interior architecture is also affected by digitalization itself a multitude of aspects. Doubtless to say that recent rise in artificial intelligence studies and application of artificial intelligence products in the field of interior architecture have also been effective factors behind the emergent trend. In the field of interior architecture, digital technology is used in two different processes: The design process of the interior space and the usage process of the interior

In the design process of interior space, use of digital technology takes place in 4 different ways: Digital Design: Drawing, modelling, presentation; Digital Production: CNC, 3D Printer, Laser 3D Scanner; Parametric Design, Animation Technologies and Virtual Reality; Digital Space Design: Cyberspace and liquid design.

For many centuries, in the design process of interior space, technical drawing, model, prototype and cast works have been used for the design and presentation stages. However not just computer-assisted design, but also development were also placed on the forefront with the onset of computer-assisted design that started in the 20th century. Still the greatest advancement of the century has been the use of robot technology in design and production processes. Fuzzy logic is actually a sought-after feature in projects for contemporary interior architecture. Through harnessing virtual reality technologies in interior space design, it was viable to develop novel design ideas and alternatives. Thus, users were able to easily define space features they needed and demanded while designers managed to express their designs in a more convenient and comfortable figure. Thanks to advanced technologies, humans were able to use public space in digital media - by using cyberspace - with no need for physical space. Weakened physical communication in spaces among humans and equipment as well as the removal of space users are among the vital factors suggested considering for designs in the future.

It is detected that inside space itself, there is an increasing need for the use of digital technologies as a result of increasingly changing technological advances, sustainability, economic well-being, satisfying conditions of comfort, easy living, and the space required by life itself. In the modern age, on the other hand, the usage process of interior space first brings to mind smart spaces that are established upon digital technology. Smart space refers to a space equipped with data processing. Within the scope of information technologies that predict and fulfil potential needs, technology management enables to control the connection of users with space and its further expansion to promote comfort, convenience, security, work, and entertainment. The scale of smart spaces is applied on a wide scale ranging from cities, structure groups, edifices, spaces to space furnishing-elements. In the future, digital technologies will be heavily used for design, production, and usage processes in all scales within every space and space element. 


\section{REFERENCES}

Akipek, F.Ö., İnceoğlu, N., "Bilgisayar Destekli Tasarım ve Üretim Teknolojilerinin Mimarlıktaki Kullanımları”. Megaron. Vol 2, No 4, 2007, pp.237253.

Aldrich, F., "Smart Homes Past, Present and Future", The Smart Home. Ed. Robert Harper, London: Springer, 2003, pp.17-39.

Atılgan D., Gelişen Tasarım ve Teknolojilerinin Mimari Tasarım Ürünleri Üzerindeki Etkileri. İzmir: Dokuz Eylül Üniversitesi Fen Bilimleri Enst. Doktora Tezi, 2006.

Cook, D.J., Sajal, K.D. Smart Environments Technologies, Protocols, And Applications. New Jersey: Wiley Interscience, 2005.

Çağlayan, S.A., Akıllı Bina Kontrol Sistemlerinin İç Mekâna Etkileri. Kocaeli: Kocaeli Üniversitesi SBE İç Mimarlık Ana Sanat Dalı Y.L.Tezi, 2002.

Çiftçi, S.K., Demirarslan, D. "Cyberpunk Genre and Interior Space Analyses of Cyberpunk Movies", IBAD Journal of Social Sciences. 2020, (Special Volume), pp. 62-83.

Demirarslan, D., İç Mekân Tasarımına Giriş. Kocaeli: Kocaeli Üniversitesi Yayınları, 2006.

Grisalena, J.A., A Brief History of Digital Architecture Historical Review and Reflections on The Relationshıp Between Architecture and Digital Tools.

PhD. Thesis in Advanced Architectural Design from the University of Alcalá, 2017.

Güntay, V., 21. "Yüzyıl Paradoksu Olarak Siber Uzay ve Uluslararası Hukuk". NOVUS ORBIS, Journal of Politics and International Relations Siyaset Bilimi ve Uluslararası İlişkiler Dergisi. Volume 1 - Number 2, 2019, pp.87-109.

Harper, R., "Ideas, Possibilities and Methods". The Smart Home. Ed. Robert Harper, London: Springer, 2003, pp.1-13.

Herzberg, C., Akıllı Şehirler Dijital Ülkeler. Istanbul: Optimist Yayın, 2017.

Gere, C., Dijital Kültür. Istanbul: Salon Yayınları, 2019.

Keyder, Ç., Ulusal Kalkınmacılığın Iflası. Istanbul: Metis Publication, Third Edition, 2004.

Nilsson, N.J. Yapay Zekâ Geçmişi ve Geleceği. Istanbul: Boğaziçi Üniversitesi Yayınevi, 2019. 
Olson, A., "How Eupalinos Navigated His Way Through the Mountain (An Empirical Approach to The Geometry of Eupalinos' Tunnel on Samos)". Anatolia Antiqua. Eski Anadolu. Vol 20, 2012, pp. 25-34.

Özdemir, S., Şahin, S., "Siberuzay Nerede?" Pivolka. No 4/19, Oct.-Dec. November 2005, pp.3-14.

Pilsitz, M., "Drawing and Drafting in Architecture Architectural History as a Part of Future Studies". Periodica Polytechnica Architecture, 48(1), pp. 72-78, 2017, https://doi.org/10.3311/PPar.11310.

Riccobono, A., Architectural Design in the Digital Era. Palermo: Universita Degli Studi di Palermo, 2013.

Roberts, J.T., Introduction to AutoCad, Oxford: Payne Gallwey Publisher, 2005.

Senagala, M., "Rethinking Smart Architecture: Some Strategic Design Frameworks". International Journal of Architectural Computing (03), volume 04, 2006, pp. 33-46.

Shih, R.H., Tools for Design Using Autocad 2020 and Autodesk Inventor 2020. USA: SDC Publications, 2020.

Şekerci, C., "Sanal Gerçekliğin İç Mekân Tasarımında Kullanımı". Uluslararası Sosyal Araştırmalar Dergisi /The Journal of International Social Research. Vol 10, No. 51, 2017, p.1357-1362.

Tunalı, Kayhan, S., "Place Attachment and the Reshaped Residence; Within the Scope of Globalization". Academic Studies in Engineering, Architecture, Planning and Design Sciences-2019/2. Ed. Tuncay Yılmaz, Can Çivi, Cetinje: Ivpe Publishing, 2019, pp.244-252.

Wingginton, M., Harris, J., Intelligent Skins. Oxford: Architectural Press, 2002.

Yankın, F. B. "Dijital Dönüşüm Sürecinde Çalışma Yaşamı". Trakya Üniversitesi Iktisadi ve Idari Bilimler Fakültesi Dergisi. E-Dergi Vol:7, No.2, 2018, pp.1-38.

Yayla, M., "Hukuki Bir Terim Olarak "Siber Savaş”". Türkiye Barolar Birliği Dergisi, sayı:104,2013, pp.177-202.

Yazar, T., Yalçın, İ., "Dijital Teknoloji ve Fotoğraf Sanatı". Uluslararası Sosyal Araştırmalar Dergisi / The Journal of International Social Research. Vol. 11, No. 60, 2018 pp.612-621 http://dx.doi.org/10.17719/jisr.2018.2813.

Yıldırım, B., Demirarslan, D., "Gözün Görme İşlevi ve Sanal İç Mimari Ürün". Mimarlık ve Yaşam Dergisi. 4(1), 2019, pp.155-165. 
Yıldıım, B., Demirarslan, D., "iç Mimarlıkta Yapay Zekâ Uygulamalarının Tasarım Sürecine Faydalarının Değerlendirilmesi". Humanities Sciences, 15 (2), 2020, pp.62-80, http://dx.doi.org/10.12739/NWSA.2020.15.2.4C0236.

URL-1: https://arthistoryproject.com/timeline/the-ancient-world/mesopotamia/ gudea-diorite-sculpture/, accessed date: 9.5.2020.

URL-2: $\quad$ https://aehistory.wordpress.com/1961/01/01/1961-computer-aideddesign-cambridge-massachusetts/102672488-03-01/, accessed date: 9.5.2020.

URL-3: https://aehistory.wordpress.com/1982/08/04/1982-autocad-v1-0/\#jpcarousel-247, accessed date: 9.5.2020.

URL-4: https://aehistory.wordpress.com/2007/10/07/2007-digital-project/dp2/, accessed date: 10.5.2020.

URL-5: https://www.robotsinarchitecture.org/kuka-prc, accessed date: 10.5.2020.

URL-6: https://aleso3d.com/, accessed date: 12.5.2020.

URL-7: $\quad$ https://all3dp.com/if-you-need-3d-printed-furniture-head-over-tokickstarter/, accessed date: 10.5.2020.

URL-8: https://www.popularmechanics.com/technology/infrastructure/ a301987 42/3d-printed-houses-neighborhood/, accessed date: 10.5.2020.

URL-9: https://www.veetildigital.com.au/good-choices-of-3d-animation-softwarefor-interior-designing, accessed date: 12.5.2020.

URL-10: https://www.maksiweb.com/responsive-tasarim/, accessed date: 12.5.2020.

URL-11: https://www.emlakbroker.com/haberler/nesnelerin-interneti-emlakdanismanlarin.html, accessed date: 12.5.2020.

URL-12: $\quad$ https://samsungrumors.net/samsung-launch-smart-building-iotsystem/, accessed date: 12.5.2020.

URL-13: https://www.iotforall.com/smart-building-technology/, accessed date: 12.5.2020. 